\title{
A QUANTITATIVE STUDY OF SOME LYSOSOMAL ENZYMES IN THE BOVINE ENDOMETRIUM DURING EARLY PREGNANCY
}

\author{
E. LINFORD AND J. M. IOSSON \\ Cattle Breeding Centre, Ministry of Agriculture, Fisheries and Food, \\ Shinfield, Reading RG2 9BZ, Berkshire
}

(Received 23rd October 1974)

\begin{abstract}
Summary. Endometrium was obtained from cattle slaughtered at various stages of early pregnancy and of the oestrous cycle. Analyses for protein, RNA, DNA, glucose and some lysosomal enzymes were carried out on this tissue. The results are considered with respect to the general influence of the hormonal status of pregnancy and the specific influence of the blastocyst in one uterine horn.
\end{abstract}

\section{INTRODUCTION}

In cattle, there is a substantial period between the recognition of the conceptus (maintenance of the CL) by the maternal tissue and the establishment of a placenta. Information on the precise timing of these events is essential to predict or determine inadequacies at this stage of pregnancy. In disease-free cattle, a major embryonic loss occurs in the 2-month period after fertilization. This loss may be due to genetic factors (David et al., 1971) or to a 'hostile' uterine environment induced, for example, by poor nutrition or abnormal blood hormone levels. This study was initiated to determine biochemical indicators of embryo/maternal contact and to demonstrate changes in the bovine endometrium which may be influenced by the hormonal status in early pregnancy.

Most of the studies of bovine endometrium have been of histological, histochemical and ultrastructural changes during the oestrous cycle (Foley \& Reece, 1953; Skjerven, 1956; Stinson et al., 1962; McQueen, 1964; Likar et al., 1964; Johnson, 1965; Kenney et al., 1965; Larson et al., 1965; Mochow \& Olds, 1966; Radman, 1967; Wrobel \& Kuhnel, 1967, Hackett \& Hafs, 1968; Leontidis, 1968; Marinov \& Lovell, 1968; Tsangaris, 1971; Veznik et al., 1972; Lawn, 1973). The effects of steroids and nutrition on these parameters have also been studied (Marion et al., 1962; Wordinger et al., 1971, 1972). The few investigations that have been carried out on the endometrium of the pregnant cow have been primarily histological (Yamauchi et al., 1968; Poon, 1971).

The endometrial lysosomes have been shown to be influenced by the maternal endocrine state (Lawn, 1973; Wood, 1973) and have been implicated in the process of implantation in the rabbit (Abraham et al., 1970), rat (Wood \& 
Psychoyos, 1967; Wood \& Barley, 1970) and sheep (Boshier, 1969; Murdoch, 1970). In the present study, the lysosomes have been examined by the complete rupture of the endometrial tissue and the assay of certain enzymes characteristic of the organelles.

\section{MATERIALS AND METHODS}

\section{Animals}

Experiment 1. Thirty-three maiden heifers (18 to 24 months of age) of various breeds were maintained for a period of time to establish their oestrous cycles. They were then allocated to control or experimental groups and those in the latter were artificially inseminated. Slaughter was arranged at the Reading abattoir at times after insemination to achieve the following categories of animals: Group A-control animals, not inseminated, and slaughtered at random stages of the oestrous cycle; Group B - animals which were inseminated but at slaughter were found to be non-pregnant; Group $\mathrm{C}$-animals 25 to 30 days pregnant (i.e. before implantation); Group $\mathrm{D}$-animals 30 to 50 days pregnant (i.e. after the expected time of implantation); Group E-animals 50 to 70 days pregnant (i.e. placenta established).

Experiment 2. Forty-three cows and heifers were slaughtered at the A.R.C. Institute for Research on Animal Diseases (I.R.A.D.), Compton, Berks. Six of these animals were maiden heifers maintained as in Exp. 1. The remaining cows and heifers were being culled for a variety of reasons from the I.R.A.D. herd and were inseminated before culling. All these animals were slaughtered at known stages of the oestrous cycle and at various times up to 23 days of pregnancy.

The definition of pregnancy in both experiments was the finding of a conceptus in the reproductive tract at slaughter. The length of pregnancy was calculated from Day 1 as the day of insemination. The difference in the location of slaughter in the two experiments must be taken into consideration since, in Exp. 1 , the reproductive tracts were available $20 \mathrm{~min}$ after slaughter whereas at I.R.A.D., the material was available within $5 \mathrm{~min}$ of slaughter.

\section{Tissue preparation}

The methods used for tissue preparation were the same in both experiments. The contents of the uterus were removed by cutting open the tract at the uterotubal junction. Careful records were kept of the state of the ovaries and the left and right horns of the uterus were identified. Each horn of the uterus was cut open along the antimesometrial side. The endometrium was then carefully stripped off from the myometrium and rinsed free of blood in physiological saline. Histological examination of this endometrial preparation showed there was a minimum of contamination by the underlying tissues.

Samples of tissue (approximately 1 to $2 \mathrm{~g}$ ) were blotted, weighed and then homogenized for $20 \mathrm{sec}$ in cold $0.9 \% \mathrm{NaCl}(1: 10 \mathrm{w} / \mathrm{v})$ by means of a Silverson homogenizer. The homogenate was centrifuged at $38,000 \mathrm{~g}$ for $30 \mathrm{~min}$ at $4^{\circ} \mathrm{C}$ and the supernatant fraction (SNF) was used for enzyme assays. The remaining endometrial tissue was frozen and stored at $-196^{\circ} \mathrm{G}$. 
Endometrial biopsy technique

To obtain endometrial tissue from non-pregnant animals by slaughter seemed unnecessary if adequate material could be obtained by means of endometrial biopsy. Griffin et al. (1974) have shown this technique (McQueen, 1967) to be satisfactory for microbiological studies of the bovine uterus. Bovine reproductive tracts were obtained from the abattoir and eleven endometrial samples of about $20 \mathrm{mg}$ were taken at random from each horn of the uterus. Six samples of endometrium, 1 to $2 \mathrm{~g}$ each, were taken from each horn of another uterus. These tissue samples were individually homogenized and assayed for protein, acid and alkaline phosphatase.

\section{Chemicals}

The chemicals purchased from Sigma London Chemical Co. Ltd were $p$-nitrophenyl phosphate, $p$-nitrophenyl- $\beta$-D-glucuronide, $O$-dianisidine, peroxidase (Type I), glucose oxidase (Type II), haemoglobin, D(-)ribose, orcinol, diphenylamine and deoxyribonucleic acid.

\section{Enzyme assays}

(a) Acid phosphatase. Samples $(100 \mu \mathrm{l})$ containing 100 to $400 \mu \mathrm{g}$ protein were incubated at $37^{\circ} \mathrm{C}$ with $500 \mu \mathrm{l} 50 \mathrm{~mm}$-citrate buffer, $\mathrm{pH} 4 \cdot 8$, containing 2.75 $\mu \mathrm{mol} p$-nitrophenyl phosphate. After $5 \mathrm{~min}$, the reaction was stopped with

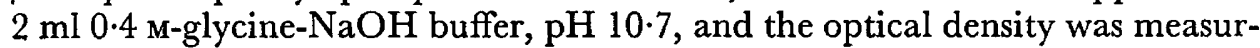
ed immediately at $405 \mathrm{~nm}$ on a spectrophotometer.

(b) $\beta$-Glucuronidase. Samples $(250 \mu \mathrm{l})$ containing 450 to $1000 \mu \mathrm{g}$ protein were incubated at $37^{\circ} \mathrm{G}$ with $1 \mathrm{ml} 0.2 \mathrm{M}$-acetate buffer, $\mathrm{pH} 4.5$, and $250 \mu \mathrm{l} 5 \mathrm{~mm}-p$ nitrophenyl- $\beta$-D-glucuronide in a total volume of $2 \mathrm{ml}$. After $60 \mathrm{~min}$, the reaction was stopped with $2 \mathrm{ml} 0.4 \mathrm{M}$-glycine- $\mathrm{NaOH}$ buffer, $\mathrm{pH} 10.7$, and the optical density was measured at $405 \mathrm{~nm}$.

(c) Alkaline phosphatase. Samples $(20 \mu \mathrm{l})$ containing 1 to $5 \mu \mathrm{g}$ protein were incubated at $37^{\circ} \mathrm{C}$ with $100 \mu \mathrm{l} 100 \mathrm{~mm}$-glycine-NaOH buffer, $\mathrm{pH} 10 \cdot 5,20 \mu \mathrm{l}$ $10 \mathrm{~mm}-\mathrm{MgCl}_{2}$ and $20 \mu \mathrm{l} 2.5 \mathrm{~mm}$ - $p$-nitrophenyl phosphate in a total volume of $200 \mu \mathrm{l}$ for $60 \mathrm{~min}$. The reaction was stopped with $2 \mathrm{ml} 0.02 \mathrm{~N}-\mathrm{NaOH}$ and the optical density of the solution was measured at $405 \mathrm{~nm}$.

(d) Acid cathepsin. Samples $(500 \mu \mathrm{l})$ containing 500 to $2000 \mu \mathrm{g}$ protein were incubated at $37^{\circ} \mathrm{C}$ with $1 \mathrm{ml}$ of $2 \%(\mathrm{w} / \mathrm{v})$ denatured haemoglobin in $50 \mathrm{~mm}$ acetate buffer, $\mathrm{pH} 3 \cdot 5$. After $60 \mathrm{~min}, 2 \mathrm{ml}$ ice-cold $5 \%$ trichloracetic acid (TCA) were added and mixed well. The protein thus precipitated after $10 \mathrm{~min}$ at room temperature was then centrifuged and 200- $\mu$ l aliquots of the supernatant were used for protein determination by the method of Lowry et al. (1951). The digestion of protein other than haemoglobin in the sample could not be measured because cathepsin $\mathrm{D}$ is known to be unstable under incubation conditions in the absence of haemoglobin (Barrett, 1972).

(e) $\mathcal{N}$-acetyl- $\beta$-glucosaminidase. Samples $(100 \mu \mathrm{l})$ containing 5 to $20 \mu \mathrm{g}$ protein were incubated with $500 \mu \mathrm{l} 100 \mathrm{~mm}$-citrate buffer, $\mathrm{pH} 5 \cdot 0,100 \mu \mathrm{l} 0 \cdot 1 \%$ (w/v) bovine serum albumin and $100 \mu \mathrm{l} 2.64 \mathrm{~mm}$-4-methyl-umbelliferyl-2-acetamido-2deoxy- $\beta$-D-glucopyranoside in a total volume of $1 \mathrm{ml}$ for $30 \mathrm{~min}$ at $37^{\circ} \mathrm{C}$. The reaction was stopped with $3 \mathrm{ml} 0.5 \mathrm{M}$-glycine- $\mathrm{NaOH}$ buffer, $\mathrm{pH} 10.5$, and 
the liberated 4-methyl-umbelliferone measured in a Model 244 EEL fluorimeter (excitation wavelength $365 \mathrm{~nm}$ and emission wavelength $460 \mathrm{~nm}$ ).

Reagent blanks for all enzyme assays were prepared by adding the enzyme samples after the reaction had been stopped. Enzymatic activity was expressed as specific activity, that is, i.u. at $37^{\circ} \mathrm{G} / \mathrm{mg}$ protein.

\section{Other analyses}

(f) Protein. Protein was determined by the method of Lowry et al. (1951).

(g) $R \mathcal{N A} A$ and $D \mathcal{N} A$. A sample $(1 \mathrm{ml})$ of the original $10 \%(\mathrm{w} / \mathrm{v})$ endometrial homogenate was mixed with $9 \mathrm{ml}$ ice-cold $5 \%$ TCA and left overnight at $4^{\circ} \mathrm{G}$. The mixture was centrifuged and the pellet resuspended in $4 \mathrm{ml} \mathrm{5 \%}$ TCA and heated at $90^{\circ} \mathrm{C}$ for $30 \mathrm{~min}$, cooled and centrifuged again. The DNA content of the SNF was determined by the method of Burton (1956) and the RNA content by the method of Korner (1959). The pellet was resuspended in $0 \cdot 1 \mathrm{~N}-\mathrm{NaOH}$ containing $2 \% \mathrm{Na}_{2} \mathrm{CO}_{3}$ and the protein content was determined.

(h) Glucose. Glucose was determined by the method of Huggett \& Nixon (1957).

\section{Statistical analyses}

Comparisons between the enzyme ratios of the cows in the various groups were made using Cochran's modified $t$ test (Snedecor \& Cochran, 1967) because heterogeneity of variances had been demonstrated by Bartlett's test (Snedecor \& Cochran, 1967).

\section{RESULTS}

The results of analyses carried out on small tissue samples of the size (about $20 \mathrm{mg}$ ) that would be obtained by an endometrial biopsy instrument are shown in Table 1(a). For comparison, the results of analyses on tissue samples of a size used in this study ( 1 to $2 \mathrm{~g}$ ) are presented in Table $1(\mathrm{~b})$. The 20-mg tissue samples gave a wider range of enzyme activities, but only two samples of this size could be taken from one uterine horn by the biopsy technique. Thus, samples taken by this procedure could not be considered to be representative of the whole endometrium.

Table 1. Results of enzyme assays carried out on bovine endometrium obtained by two different sampling techniques

\begin{tabular}{|c|c|c|}
\hline Tissue & $\begin{array}{c}\text { Acid } \\
\text { phosphatase }\end{array}$ & $\begin{array}{c}\text { Alkaline } \\
\text { phosphatase }\end{array}$ \\
\hline $\begin{array}{l}\text { (a) Eleven samples of } 20 \mathrm{mg} \text { each } \\
\text { Left horn } \\
\text { Right horn }\end{array}$ & $\begin{array}{l}7.2(2.5 \text { to } 11.2) \\
7.2(1.5 \text { to } 12.2)\end{array}$ & $\begin{array}{r}150.0(30.0 \text { to } 261 \cdot 7) \\
83.3(6.7 \text { to } 161 \cdot 7)\end{array}$ \\
\hline $\begin{array}{l}\text { (b) Six samples of } 2 \mathrm{~g} \text { each } \\
\text { Left horn } \\
\text { Right horn }\end{array}$ & $\begin{array}{l}11.6(10.4 \text { to } 12.7) \\
10.2(8.8 \text { to } 11.8)\end{array}$ & $\begin{array}{l}216.7(196.7 \text { to } 258.3) \\
250.0(221.7 \text { to } 286.7)\end{array}$ \\
\hline
\end{tabular}

Values (in i.u. $\times 10^{3} / \mathrm{mg}$ protein) are means with the range in parentheses. 


\section{Experiment 1}

The levels of the non-enzymatic components of the endometrial tissues are presented in Text-fig. 1(a). Group D is not represented for some components because the animals were slaughtered before all the assay routines were established. There were no marked differences in the levels of glucose, RNA and DNA between the Groups A and B (non-pregnant animals), but the level of protein/ml supernatant was significantly lower in Group-B animals which had been inseminated. No differences were seen between the levels of all the components in the two horns of the uterus of the non-pregnant animals (Groups $A$ and B). In animals in Group C, there was a reduction in the RNA:DNA ratio of the endometrium and differences between the uterine horns with respect to glucose and protein. The difference between horns in $\mathrm{mg}$ protein $/ \mathrm{ml}$ $\mathrm{SNF}$ in Group $\mathrm{C}$ appeared to result from a difference in water content of the tissue since there was no difference between the horns in mg DNA/mg protein. In Groups $\mathrm{D}$ and $\mathrm{E}$, there were differences in protein content and in $\mathrm{mg}$ $\mathrm{DNA} / \mathrm{mg}$ protein in the horns. At the latest stage of pregnancy studied (Group
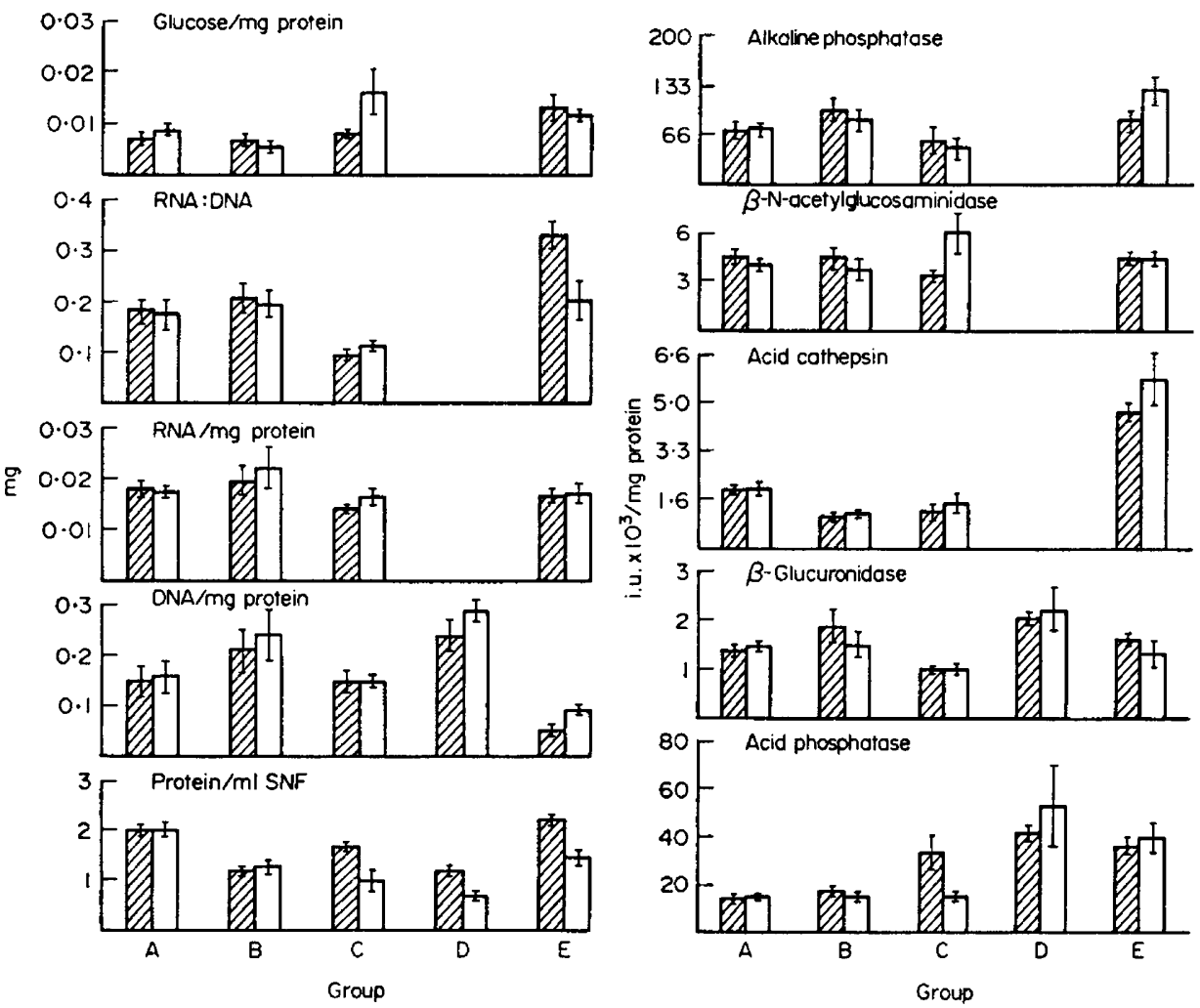

TexT-FIG. 1. The mean levels ( \pm S.E.M.) of (a) protein, DNA, RNA and glucose, and (b) specific activities of some lysosomal hydrolases in bovine endometrium. Hatched columns represent the horn ipsilateral to the ovary with the CL or follicle and open columns represent the contralateral horns. Group A, animals that had never been inseminated; Group B, animals that were inseminated but were not pregnant at slaughter; Group C, animals slaughtered at 25 to 30 days of pregnancy; Group D, animals slaughtered at 30 to 50 days of pregnancy; Group $\mathrm{E}$, animals slaughtered at 50 to 70 days of pregnancy. 


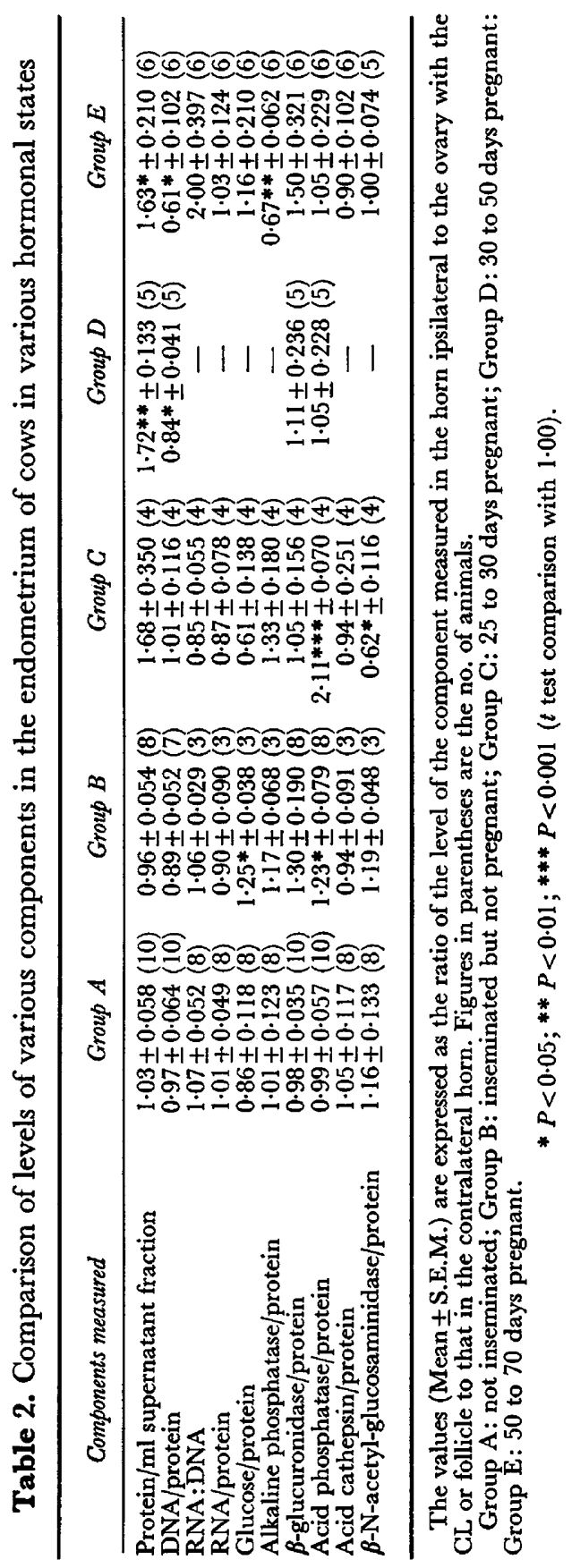




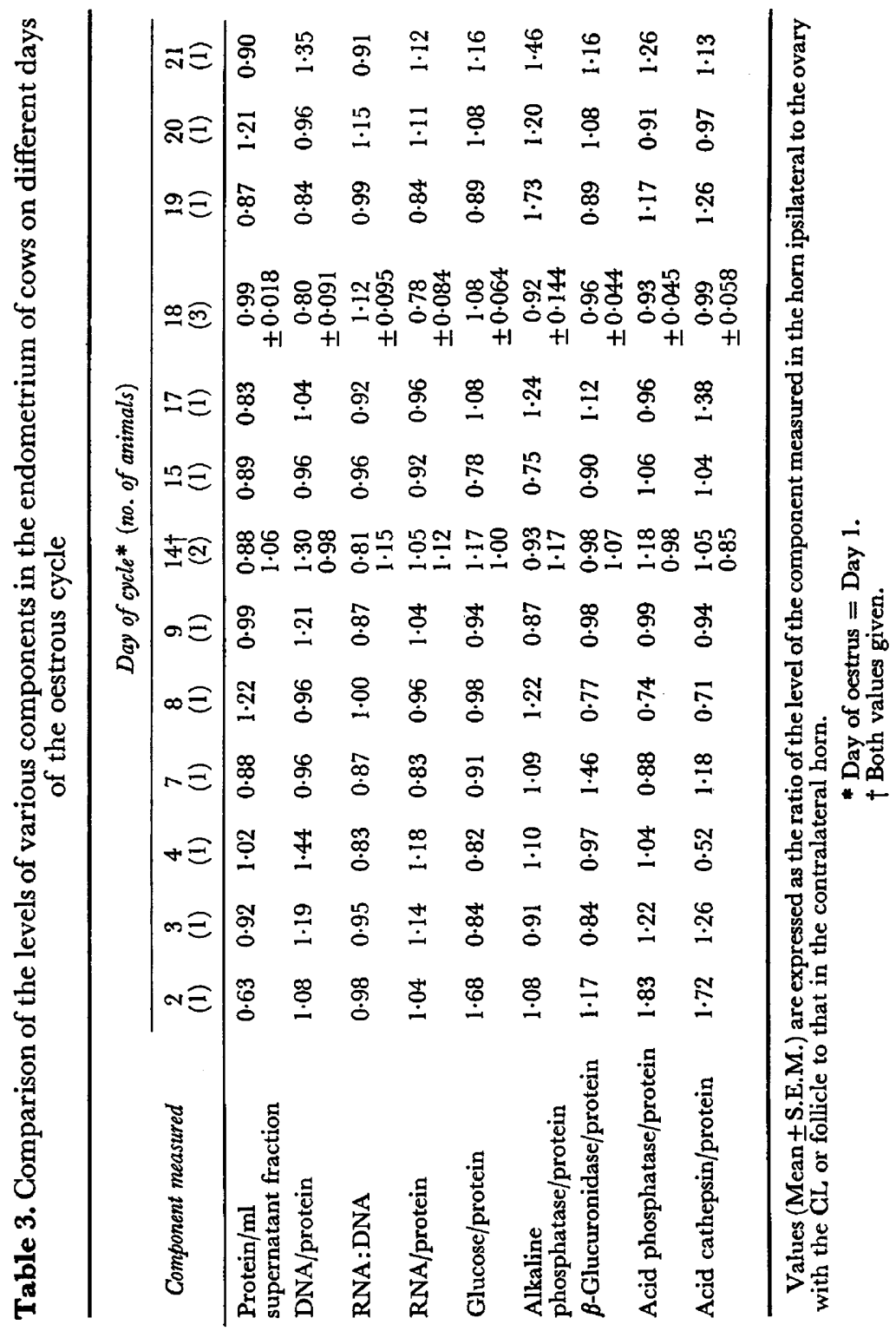




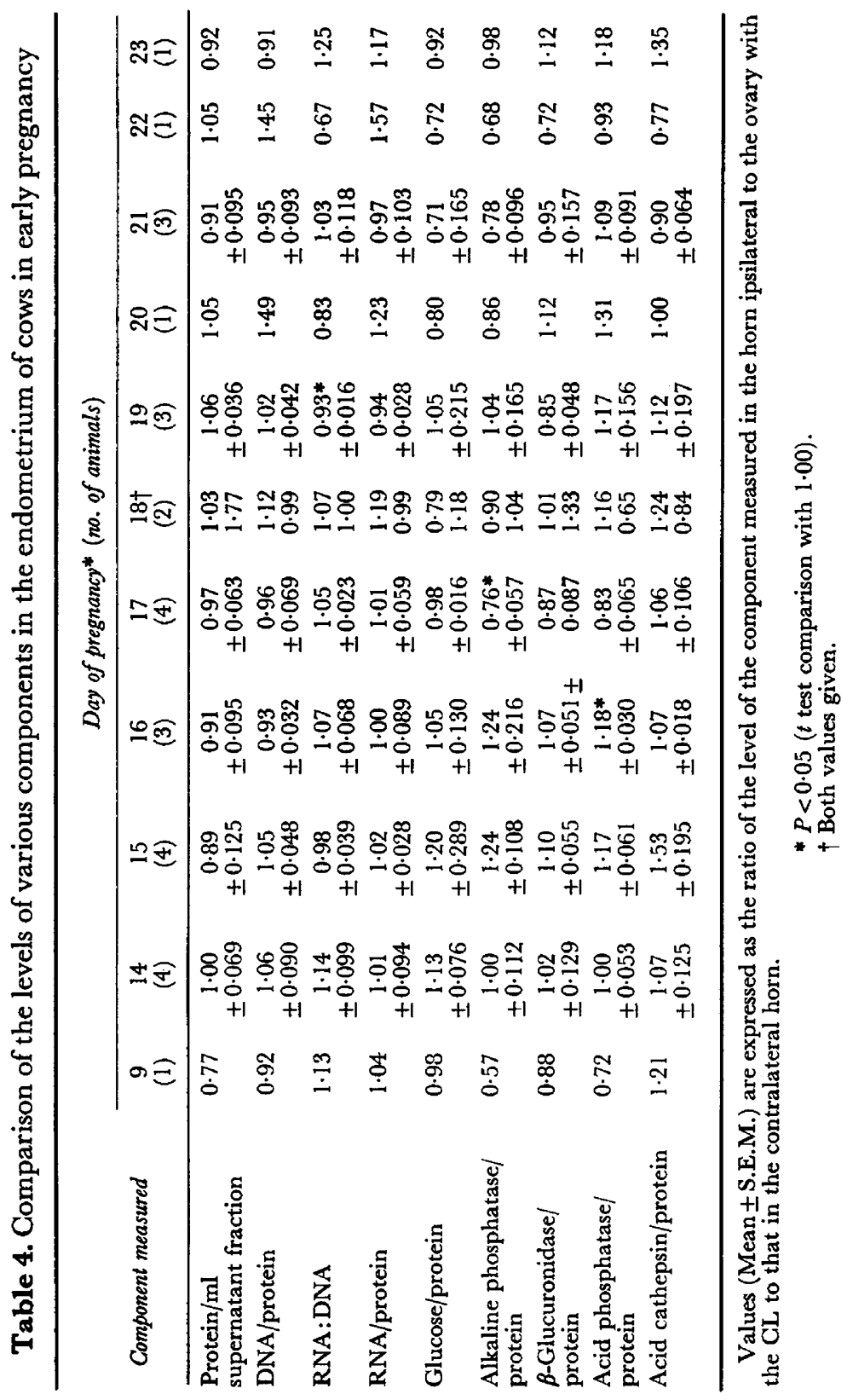


E), there was a marked drop in the DNA/mg protein and a marked difference in the RNA:DNA ratio between the uterine horns.

The specific activities of four lysosomal enzymes and alkaline phosphatase are shown in Text-fig. 1(b). Acid phosphatase was higher in endometrium from pregnant animals (Groups $\mathrm{C}, \mathrm{D}$ and $\mathrm{E}$ ) than in that from non-pregnant animals (Groups A and B). Activities of $\beta$-glucuronidase and $\beta$-N-acetylglucosaminidase, both lysosomal enzymes, were not higher in pregnancy and it was only at the later stage of pregnancy (Group E) that acid cathepsin showed a dramatic increase in activity.

The differences between the uterine horns shown by some of these parameters could be misleading because of individual variation and the small number of animals in each group. For this reason, the data were transformed by dividing the level of each component in the uterine horn ipsilateral to the ovary with the GL or follicle by the level in the contralateral horn, thus yielding a ratio of 1.00 if no difference between the horns exists; $t$ tests of comparison with 1.00 could then be carried out. The ratios thus calculated for all parameters are presented in Table 2. In the control group (Group A), none of the ratios differed significantly from 1.00 . In those animals that were inseminated but were not pregnant (Group B), the ratios for acid phosphatase and glucose were significantly greater than $1.00(P<0.05)$. In Group $\mathrm{G}(25$ to 30 days pregnant), the ratios showed that the level of acid phosphatase in the endometrium of the pregnant horn was double that of the empty horn $(P<0.001)$, but this ratio was not maintained at later stages of pregnancy (Groups $D$ and $E$ ). The level of acid phosphatase differed between Groups $A$ and $B$ and between Groups B and C. The other lysosomal enzymes did not show a similar distribution; in fact, the ratio for $\beta$-N-acetyl-glucosaminidase was less than 1.00 $(P<0.05)$ in the pregnant horn endometrium in Group-C animals. The higher levels of protein in the pregnant horns shown in Text-fig. 1(a) were confirmed by the ratios (Table 2) although the variation in analyses of Group $\mathrm{C}$ was higher. Alkaline phosphatase was found to be higher $(P<0 \cdot 01)$ in the endometrium of the empty horn of Group-E animals.

\section{Experiment 2}

The results of the analyses are presented (Tables 3 and 4) only as uterine horn ratios (see above). Only ratios for RNA:DNA, acid and alkaline phosphatase in the pregnant animals were significantly different from 1.00 (Table 4).

\section{DISCUSSION}

The response of the endometrium to the state of pregnancy will depend on the systemic effect of the continuous secretion of progesterone by the maintained GL and the local effect of the presence of the conceptus in one horn of the uterus. At the latest stage of pregnancy studied (50 to 70 days), when both these factors would be effective, the increase in the endometrial activities or levels of acid phosphatase, acid cathepsin, glucose and the RNA:DNA ratio and the decrease in the DNA content, indicated a general increase in the synthetic activity of the uterine tissue. At 25 to 30 days of pregnancy (Group $\mathrm{C}$ ) the placenta was not established and changes in the endometrium (an increase in acid phosphatase activity and glucose content) may have been the result of 
continuing high plasma progesterone levels (Robertson \& Sarda, 1971). Although the results are incomplete for the intermediate stage in pregnancy (Group D), acid phosphatase activity was higher than in endometrium from non-pregnant animals (Text-fig. 1b). The changes in acid phosphatase during pregnancy were not shown by other lysosomal enzymes or by alkaline phosphatase. By contrast, Murdoch (1970, 1972a, b) showed that, in early pregnancy in rabbits and ewes, increases in endometrial acid phosphatase were accompanied by similar changes in alkaline phosphatase. In his analyses, Murdoch distinguished between the cotyledonary and intercotyledonary areas of the endometrium but combined the two uterine horns. In the present study, no distinction was made between the cotyledonary and intercotyledonary areas of the endometrium but some indication of a non-random distribution of enzyme activity in the endometrium from pregnant animals is given by the increased variation in the results, especially those for acid phosphatase (Text-fig. 1b). Murdoch (1972b) was able to induce increases in endometrial phosphatase by progesterone treatment of ewes, but he did not consider the hormone to be solely responsible for the enzyme control. Our results provide evidence that, in addition to the effect of altered levels of circulating hormones in pregnancy, the presence of the conceptus itself has a local effect on some biochemical parameters of the endometrium. Since relatively large samples of endometrium were analysed, the local effect of the conceptus could not have been restricted to a small area of tissue. It seems likely that the fetal membranes may be responsible for the effect on the endometrium. This would account for the loss of the difference between the horns in acid phosphatase activity at later stages of pregnancy when the fetal membranes extend into both horns. There is then, however, no explanation for the difference in protein, DNA and alkaline phosphatase in the uterine horns at 50 to 70 days of pregnancy (Table 2). The lower levels of alkaline phosphatase and DNA in the horn containing the embryo at this stage of pregnancy may be artifacts since they were expressed in terms of protein, which itself showed a significant increase in the pregnant horn at that time. As Murdoch (1972b) suggested for the ewe, it seems that the bovine endometrium needs to be primed with progesterone, but there also appears to be a local effect of the conceptus which is transitory for acid phosphatase and prolonged for the RNA:DNA ratio. Studies on steroid synthesis by pig blastocysts (Perry et al., 1973) indicate one possible means by which this local endometrial response may be effected.

Our results show that there were marked differences in the endometrium between the animals that had been inseminated but were not pregnant at slaughter and animals that had never been inseminated (Table 2). This is an important distinction since it is tempting to use the former animals as 'controls'. An explanation of these differences is that fertilization may have been successful but the embryo was lost before slaughter. The presence of the embryo may then have been responsible for the uterine horn differences seen in acid phosphatase and glucose (Table 2). The results of Exp. 2, in which animals were killed at random during the 21 days after insemination or oestrus, should have given further information on this aspect. The individual variation was high and, with small numbers in each group, comparison was not satisfactory. No attempt has been made to group the animals as physiological events at this stage may 
be short-lived. At 21 days, there were significant differences between the horns (Table 4) in the levels of endometrial phosphatase in the pregnant animals compared with those in non-pregnant cows. This very early stage of pregnancy is the subject of our present studies.

It is generally accepted that acid phosphatase is a marker enzyme for lysosomes. Boshier (1969) concluded from his histological and histochemical study of the ewe uterus that the changes in acid phosphatase levels indicated the involvement of lysosomes in the implantation process. The changes in acid phosphatase reported here, however, cannot be assumed to indicate changes in lysosomes alone, particularly when other lysosomal enzymes did not show similar changes. Beaufay (1972) stressed that $p$-nitrophenyl phosphatase activity is not synonymous with lysosomal acid phosphatase activity. Indeed, our recent studies (E. Linford and J. Iosson, unpublished data) indicated that the changes in acid phosphatase activity reported here may consist of changes in a labile phosphatase activity not associated with lysosomes. The possibility that various physiological states induce changes in the properties of the enzymes cannot be excluded. This may result in more enzyme being released into the soluble phase at homogenization.

The endometrial changes reported in this study may be of no physiological significance in themselves but, if they are reliable, may be used to indicate or monitor the uterine response to early pregnancy. This study also reveals the possible dangers of attributing physiological significance to specific events monitored by non-specific methods of determination.

\section{ACKNOWLEDGMENTS}

We wish to thank the staff of the Cattle Breeding Centre and of the I.R.A.D., Compton, who gave us assistance with this study.

\section{REFERENCES}

Abraham, R., Hendy, R., Dougherty, W.J., Fulfs, J.C. \& Golberg, L. (1970) Participation of lysosomes in early implantation in the rabbit. Expl molec. Path. 13, 329-345.

BARRetT, A. J. (1972) Lysosomal enzymes. In Lysosomes. A Laboratory Handbook, p. 125. Ed. J. T. Dingle. North-Holland Publishing Company, Amsterdam and London.

Beaupay, H. (1972) Methods for the isolation of lysosomes. In Lysosomes. A Laboratory Handbook, p. 33. Ed. J. T. Dingle. North-Holland, Amsterdam and London.

Boshier, D.P. (1969) A histological and histochemical examination of implantation and early placentome formation in sheep. F. Reprod. Fert. 19, 51-61.

Burton, K. (1956) A study of the conditions and mechanism of the diphenylamine reaction for the colorimetric estimation of deoxyribonucleic acid. Biochem. 7. 62, 315.

DAvid, J.S.E., BISHOP, M.W.H. \& CemBrowicz, H.J. (1971) Reproductive expectancy and infertility in cattle. Vet. Rec. 89, 181-185.

Foley, R.C. \& REECE, R.P. (1953) Histological studies of the bovine uterus, placenta, and corpus luteum. Bull. Mass. agric. Exp. Stn, No. 468.

Griffin, J.F.T., Murphy, J.A., NUnN, W.R. \& Hartigan, P.J. (1974) Repetitive in vivo sampling of the bovine uterus under field conditions. Br. vet. $7.130,259-264$.

HACKETT, A. J. \& HAFS, H.D. (1968) Some histological and biochemical changes in the bovine reproductive tract during the estrous cycle. Proc. gen. Soc. \& West. Brch Can. Soc. Anim. Prod.p. 29, Abstr.

Huggetr, A.St G. \& Nixon, D.A. (1957) Enzymic determination of blood glucose. Biochem. F. 66, 12P.

Johnson, K.R. (1965) Cyclic histological changes occurring in the endometrium of the bovine. Res. Bull. Idaho agric. Exp. Stn No. 63.

KENNEY, R.M., Usur, K. \& McEnTEe, K. (1965) Some histochemical and biochemical enzymatic parameters of the oestrous cycle of the bovine endometrium. F. Am. vet. med. Ass. 147, 1660. 
Korner, A. (1959) The effect of hypophysectomy of the rat and of treatment with growth hormone on the incorporation of amino acids into liver proteins in a cell-free system. Biochem. $7.73,61-71$.

Larson, L.L., Marion, G.B. \& Grer, H.T. (1965) Cyclic changes in the bovine endometrium. $\mathcal{F}$. Anim. Sci. 24, 923, Abstr.

LAwn, A.M. (1973) The ultrastructure of the endometrium during the sexual cycle. Adv. Reprod. Physiol. 6, 61-95.

Leontidis, S.L. (1968) Histological and histochemical investigation of the bovine endometrium. Epistem. Epet. klen. Skhol. (Scient. Yb. vet. Fac.), Thessalonoki 9, 473-569.

Likar, I.N., Likar, L.J. \& Robinson, R.W. (1964) Mast cells and hyaluronic acid in the bovine endometrium. Nature, Lond. 203, 730-733.

Lowry, O.H., Rosebrough, L.J., Farr, A.L. \& Randall, R.J. (1951) Protein measurement with the Folin phenol reagent. $\mathcal{F}$. biol. Chem. 193, 265-275.

McQueen, R.D. (1964) Cyclic changes in the gland cell ultrastructure and in the specific activity of ribonucleic acid, protein and phospholipid of the endometrium of mature dairy cattle. Diss. Abstr. 25, 1297.

MaQueEN, R.D. (1967) A biopsy instrument for obtaining bovine endometrial samples for histologic and metabolic investigations. Am. 7. vet. Res. 28, 1881-1885.

Marinov, U. \& Lovell, J.E. (1968) Cytology of the bovine uterine epithelium during the estrous cycle. Am. J. vet. Res. 29, 13-30.

Marion, G.B., Norwood, J.S., Darwash, A.D. \& Gier, H.T. (1962) Effects of steroid hormones on the bovine uterine epithelium. F. Anim. Sci. 21, 1026, Abstr.

Mochow, R. \& Olds, D. (1966) Effect of age and number of calvings on histological characteristics of the bovine uterus. F. Dairy Sci. 49, 642-646.

Murdoch, R.N. (1970) Glycogen, glycogen-metabolizing enzymes, and acid and alkaline phosphatases in the endometrium of the ewe during early pregnancy. Aust. 7. biol. Sci. 23, 1289-1296.

Murdoch, R.N. (1972a) Changes in acid and alkaline phosphatase activities in the uterus and oviduct of the rabbit doe during early pregnancy. Aust. J. biol. Sci. 25, 387-396.

Murdoch, R.N. (1972b) Phosphomonoesterases and histamine in the uterus of the ewe during early pregnancy. Aust. F. biol. Sci. 25, 1289-1297.

Perry, J.S., Heap, R.B. \& Amoroso, E.G. (1973) Steroid hormone production by pig blastocysts. Nature, Lond. 245, 45-47.

Poon, C.H. (1971) Ultrastructure of the bovine endometrial glandular cells at 3, 8 and 18 days postmating. Diss. Abstr. int. 32B, 530.

RADMAN, Z. (1967) The histologic and some histochemical variations of the bovine endometrium in the course of the sexual cycle. Vet. Arh. 37, 250-255.

Robertson, H.A. \& SARda, I.R. (1971) A very early pregnancy test for mammals: its application to the cow, ewe and sow. $\mathcal{F}$. Endocr. 49, 407-419.

SkJerven, O. (1956) Endometrial biopsy studies in reproductively normal cattle. Clinical, histochemical and histological observations during the estrous cycle. Acta endocr., Copenh., Suppl. 26.

Snedecor, G.W. \& Cochran, W.G. (1967) Statistical Methods. Iowa State University Press, Iowa.

Stinson, A.W., Weber, A.F. \& Zemjanis, R. (1962) The bovine endometrium-an electron microscopic study. Am. J. vet. Res. 23, 1164-1181.

TSANGARIS, T. (1971) Electron microscope picture of the endometrium of the cow during the sexual cycle. Zentbl. VetMed. 18, 842-866.

Veznix, Z., Hruska, K.J. \& Kummer, V. (1972) Morphological and biochemical changes in the endometrium of dairy cattle during the ovarian cycle. Proc. 7th Int. Congr. Anim. Reprod. \& A.I., Munich, 799-803.

Wood, J.C. (1973) Lysosomes of the uterus. Adv. Reprod. Physiol. 6, 221-277.

Wood, J.C. \& Barley, V.L. (1970) Biochemical changes in forming and regressing deciduoma in the rat uterus. F. Reprod. Fert. 23, 469-475.

Wood, J.C. \& Psychoyos, A. (1967) Activité de certaines enzymes hydrolytiques dans l'endomètre et myomètre au course de la pseudogestation et de divers états de récepitivté utérine chez la Ratte. C. r. hebd. Séanc. Acad. Sci., Paris 265, 141-144.

Wordinger, R.J., Dickey, J.F. \& Hill, J.R. (1971) Histological and histochemical changes in bovine endometrium following treatment with a progestin. . Dairy Sci. 54, 1872-1875.

Wordinger, R.J., Dickey, J.F. \& Hill, J.R. (1972) Influence of under-nutrition on the histology and histochemistry of the bovine endometrium. 7. Anim. Sci. 34, 453-459.

Wronel, K.H. \& KuHnel, W. (1967) Die histotopik einiger wasserstoffüber-tragender Enzyme in Rinderendometrium während der späten Follikelphase. Zuchthygiene 2, 24-30.

Yamauchi, S., Kotera, K. \& KaKishita, T. (1968) Histological study of the pregnant uterus in the cow. 1. General histology of the endometrium of the intercaruncular area. Fap. F. zootech. Sci. $39,487-504$. 